\title{
A SYSTEMATIC REPLICATION OF SKINNER (1938) USING A HOT AIR BLAST AS THE PUNISHER
}

\section{UMA REPLICAÇÃO SISTEMÁTICA DE SKINNER (1938) USANDO O JATO DE AR QUENTE}

\author{
PaUlo CÉsar Morales Mayer \\ UNIVERSIDADE ESTADUAL DO OESTE DO PARANÁ, BRASIL \\ MARCus BeNTES DE CARVALHO NeTO \\ UNIVERSIDADE FEDERAL DO PARÁ, BRASIL
}

\section{RESUMO}

O presente estudo é uma replicação sistemática do estudo clássico de Skinner (1938) usando um Jato de Ar Quente (JAQ) como punidor. Após o estabelecimento da resposta de pressionar a barra, seis ratos foram submetidos a duas sessões de extinção. Durante os 10 minutos iniciais da primeira sessão de extinção, metade dos sujeitos recebeu um JAQ para cada pressão à barra (punição). Os sujeitos que tiveram suas respostas punidas apresentaram uma supressão parcial dessa classe durante toda primeira sessão de extinção. No entanto, no final da segunda sessão de extinção, o número total de respostas para ambos os grupos (punido e não-punido) foi equivalente. Os presentes dados corroboram os achados de Skinner (1938) de que a punição pode ter efeitos parciais e temporários em determinados contextos. Por fim, discute-se como a eliciação de respostas competitivas, a intensidade e a natureza do estímulo e a duração da exposição à contingência aversiva seriam fatores importantes para explicar os resultados divergentes da literatura.

Palavras-chave: punição, replicação, respostas competitivas, supressão, ratos, jato de ar quente

\section{ABSTRACT}

The present study was a systematic replication of the classic study by Skinner (1938) using a hot air blast $(\mathrm{HAB})$ as the punisher. After lever press training, six rats underwent two extinction sessions. During the initial $10 \mathrm{~min}$ of extinction in the first session, half of the subjects received a HAB for every lever press (punishment). Subjects that received punishment made fewer lever presses during first extinction session, but the total number of responses in both groups was equivalent by the end of the second extinction session. The present data corroborate the findings of Skinner (1938) that the punishment may have partial and temporary effects in certain contexts. We discuss the ways in which the elicitation of competitive responses, the intensity and nature of the stimulus, and the duration of exposure to the aversive contingency are important factors that may explain the divergent results in the literature.

Keywords: punishment, replication, competitive responses, suppression, rats, hot air blast

\footnotetext{
This research was supported by CAPES (Doctoral scholarship and Post-Doctoral Scholarship - PNPD for the first author) and by CNPq (Grant Number 476839/2013-0, Edital Universal, and a research productivity fellowship, awarded to the second author). The authors thank Gisele Fernandez da Silva and Renata Almeida Figueira for their help on the conduction of the experiment. We thank two anonymous reviewers and Paula Debert for their criticisms that improved the manuscript. Correspondence should be sent to Paulo César Morales Mayer (paulocmayer@gmail.com) or Marcus Bentes de Carvalho Neto (marcusbentesufpa@gmail.com)
} 
The behavioral processes that are responsible for suppressing behavior in punishment contingencies is a highly debated topic (Arbuckle \& Lattal, 1987; Azrin \& Holz, 1966; de Villiers, 1980; Dinsmoor, 1998; Kubanek, Snyder, \& Abrams, 2015; Paton \& Louie, 2012; Rachlin \& Herrnstein, 1969; Rasmussen \& Newland, 2008; Skinner, 1938/1991, 1953). Theories usually advocate either of two perspectives: direct or competitive suppression. Direct suppression presumes that the observed suppression is caused by a direct learning process between the behavior and consequence, decreasing the probability of the punished response (Azrin \& Holz, 1966; Catania, 1998). Competitive suppression is presumed to result from behavioral displacement through responses that compete with the punished response. Such competitive responses can be respondent (i.e., produced by contact with a punishing consequence or by a conditioned stimulus) or operant (i.e., produced by an automatic reinforcement of any response that prevents contact with the punishing stimulus; Sidman, 1989; Skinner, 1953).

One of the earliest and most cited studies that favor the competitive perspective is the experiment that was described by Skinner (1938/1991, Chapter 4, p. 154). In this study, eight food-deprived rats were trained to press a lever for food pellets under a fixedinterval (FI) 4-min schedule. After three sessions, lever pressing was placed under extinction conditions in two 120-min sessions. For half of the subjects during the initial $10 \mathrm{~min}$ of the first extinction session, each lever press produced a reverse movement of the lever that slapped the rat's forepaw. Skinner reasoned that if punishment directly reduces the probability of responding, then the subjects that are submitted to punishment would perform fewer responses during the course of extinction. During the first 10min of extinction, the subjects in the punishment group made fewer lever presses than the unpunished group. However, when the punishment contingency was discontinued, the response rate abruptly increased in the punished group, indicating compensatory responding. By the end of the second extinction session, both groups made a similar number of total lever press responses.

Skinner (1938/1991) stated that the punishment did not affect the response probability itself but rather produced a range of responses that prevented the subjects from pressing the lever. He referred to such responses as "emotional responses." As time elapsed and punishment was not in effect anymore, the competitive responses extinguished, and lever pressing occurred with its usual probability. Two replications of this experiment were found in the literature, and both of them used electric shock instead of the "bar-slap." Estes (1944, Experiment A) reproduced Skinner's results, whereas Boe and Church (1967, Experiment 1) used various shock intensities and observed fewer responses in the punished groups, even at the lowest shock intensity (35 V).

Electric shock is the default stimulus in punishment experiments with nonhuman subjects because it is effective, can be quickly introduced and removed, and can be tested with a broad range of intensities and duration with great precision (Dinsmoor, 1998). Such characteristics facilitate replication and comparisons between studies. However, electric shock can also produce an array of physiological reactions (Flaherty, 1985) that most likely do not occur with other aversive stimuli. Thus, many authors argue that alternative aversive stimuli should be used to test the generality of behavioral principles that were previously established with electric shock (Barker et al., 2010; Branch, Nicholson, \& Dworkin, 1977; Carvalho Neto et al., 2005; Catania, 1998; Church, 1969; Lerman \& Vorndran, 2002; Mayer, Silva, \& Carvalho Neto, 2015). One issue is whether the same behavioral mechanism is in effect when the consequence of responding is either an electric shock or a milder and less disruptive stimulus (as in Skinner, 1938/1991).

Since 2005, the hot air blast (HAB) has been tested with different aversive contingencies. It appears to be a promising alternative to electric shock because of its functional equivalence and because it does not elicit incompatible physiological responses or limit motor activity (Nascimento \& Carvalho Neto, 2011). The HAB has been an effective punisher in both continuous and intermittent schedules (Carvalho Neto et al., 2005; Carvalho Neto, Maestri, \& Menezes, 2007; Mayer et al., 2015) and in discriminated punishment (Carvalho Neto, Costa, Barros, Farias, \& Rico, 2013). It has also been effective in strengthening escape responses and producing learned helplessness (Maestri, 2008) and conditioned suppression (Nascimento \& Carvalho Neto, 2011; Nascimento, Monteiro, Gouveia, \& Carvalho Neto, 2012).

Replication is a cornerstone of science that helps elucidate the necessary and sufficient conditions for a phenomenon to occur and limitations of analysis and conclusions. Although the aforementioned punishment experiment that was performed by Skinner (1938/1991) is still a classic study that supports Skinner's view on the subject among behavior analysts, only two replications of the study were found in the literature, and these two studies reported different results (Estes, 1944; Boe \& Church, 1967) using the same stimulus (electric shock). The present study was a systematic replication of the punishment study by Skinner (1938/1991). We sought to verify the effects of the $\mathrm{HAB}$ as a punisher on the probability of a response class that is punished during extinction. We also discuss some issues that were raised by Skinner regarding the suppression of responding by punishment. 


\section{METHODS}

\section{Subjects}

The subjects were six male Long-Evans rats, 3 months old at the beginning of the experiment. They were provided by Instituto Evandro Chagas (Ananindeua, Paraná, Brazil) and housed in individual cages with free access to food. Water was available for $10 \mathrm{~min}$ after a minimum of $30 \mathrm{~min}$ after each session. The experiment occurred during the light phase of a $12 \mathrm{~h} / 12 \mathrm{~h}$ light/dark cycle. Care for the subjects was in accordance with the guidelines of the APA Ethical Principles and Brazilian College of Animal Experimentation (COBEA) ${ }^{1}$.

\section{Materials and Equipment}

The experimental chambers comprised four Skinner boxes (Mod. 3, Insight Equipment) with one lever in the central position of the right wall and a dipper (20 ml cup of water) located below the lever. Two of these boxes were adapted for HAB use. The ceiling was replaced with an iron grate to enable delivery of the HAB. The floor grid was replaced by acrylic bars. An acrylic sheet was glued on top of the lever. These acrylic sheets were used to minimize the cumulative effect of heat from the HAB. Two common household blow dryers (Revlon, model RV429AB) were positioned on top of the box, one above the lever and another on the extreme left side of the box. The blow dryers were manually activated by the experimenter at their maximum intensity using a switch that was connected in series to an extension cord. After being activated for $5 \mathrm{~s}$, the chamber's temperature (about $24^{\circ} \mathrm{C}$ ) increased by about $4^{\circ} \mathrm{C}$. The air pressure of the $\mathrm{HAB}^{2}$ was $216.5 \mathrm{dyn} / \mathrm{cm}^{2}$, and the noise of each blow dryer was about $85 \mathrm{~dB}$.

\section{Procedures}

The subjects were water-deprived for $48 \mathrm{~h}$ before each session. The deprivation time was justified by the high levels of humidity in the city where the experiment was conducted (usually > $80 \%$ ).

During Phase 1, eight sessions were conducted, comprising lever press shaping, continuous reinforcement, and extinction. Sessions one through six lasted 30min and were performed once per week. Sessions seven and eight lasted for $1 \mathrm{~h}$, and each lever press produced one drop of water. From session seven onward, sessions occurred every 2 days. The rats that were used in this experiment were provided after being used in an undergraduate

\footnotetext{
${ }^{1}$ The present study did not receive an ethics committee approval number because the data were collected in 2011, prior to the current national protocol for research with nonhuman animals. We followed the same principles that are promulgated by the APA Ethical Principles and COBEA.

${ }^{2}$ An automated version of the HAB, adapted to the MED equipment can be found in Mayer, Silva, and Carvalho Neto (2015).
}

experimental psychology course. All of the procedures that were performed in this course are described in this Phase 1.

For Phase 2, the subjects were randomly assigned to one of two groups: HAB or Extinction (EXT). For the HAB group, sessions were conducted in the adapted chambers. Phase 2 comprised three 60 min sessions, during which lever presses produced water on an FI-4 min schedule. During the first session, the intervals were progressively increased (five reinforcers for 30, 45, 60, and 90; three reinforcers for 120, 180, and 240s). Phase 3 comprised two $2 \mathrm{~h}$ sessions of extinction (lever presses did not produce water). For the HAB group, during the first $10 \mathrm{~min}$ of the first extinction session, each lever press activated the HAB for $5 \mathrm{~s}$. Activation of the HAB was not cumulative, additional lever presses while the HAB was activated did not extend the duration of the HAB.

During each session, the number of lever presses per minute was recorded using an automated digital recorder that was connected to the lever. The percentage of responses during the extinction sessions was calculated based on the total responses in the last FI session to allow proportional comparisons among subjects.

\section{RESULTS}

Figure 1 shows that the HAB group made fewer lever presses (14 vs. 95 responses) during the initial $10 \mathrm{~min}$ of extinction when the punishment contingency was in effect. This difference decreased throughout the extinction sessions. After 100min of extinction, the two groups presented no differences in the number of lever presses.

The individual data that are presented in Figure 2 indicate mixed results for the HAB group compared with the Ext group. During first 10min of Phase 3 when the punishment contingency was in effect, all of the subjects in the HAB group responded less than the Ext group, but higher response rates were observed in the $\mathrm{HAB}$ group during the next $20 \mathrm{~min}$ after punishment (i.e., minutes 10-30). From minute 30 to the end of Day 1, the curves for subjects HAB1 and HAB2 were indistinguishable from the curves for Ext subjects. Subject HAB3 exhibited a decrease in responding after minute 20 of Day 1, and the total responding for this animal remained below any frequency that was observed for Ext subjects until the end of the study. Subject HAB 1 continued to respond similarly to the subjects in the Ext group during Day 2, with higher rates of responding during the first half of the session followed by lower and more spaced responding. Subject HAB2 responded at almost constant rates throughout the session (approximately 3 responses/minute), reaching the highest total responding observed (even compared with EXT subjects). 


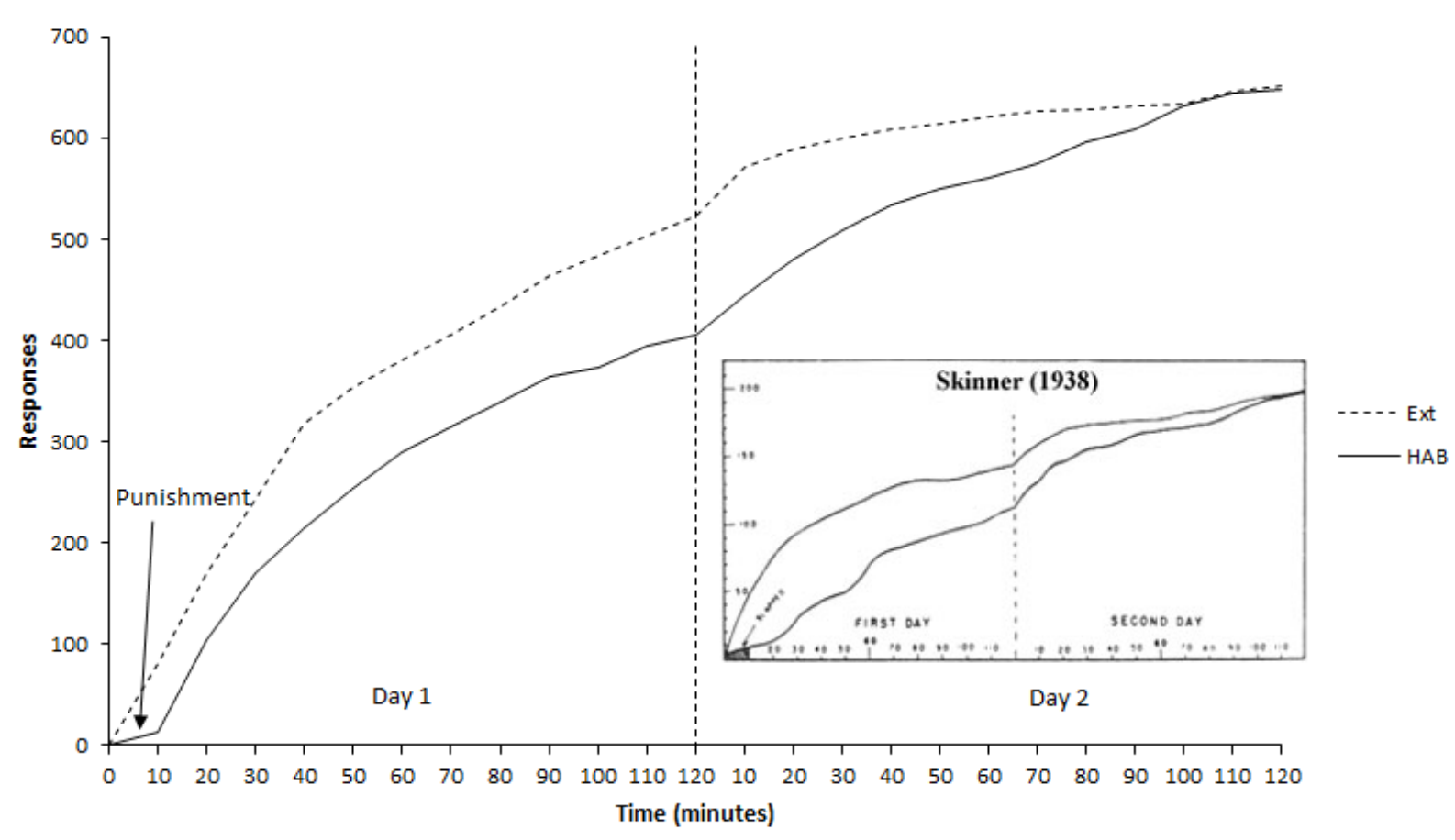

Figure 1. Mean cumulative record of lever presses during Phase 3 in each group compared with Skinner (1938) (inset; reproduced with permission).

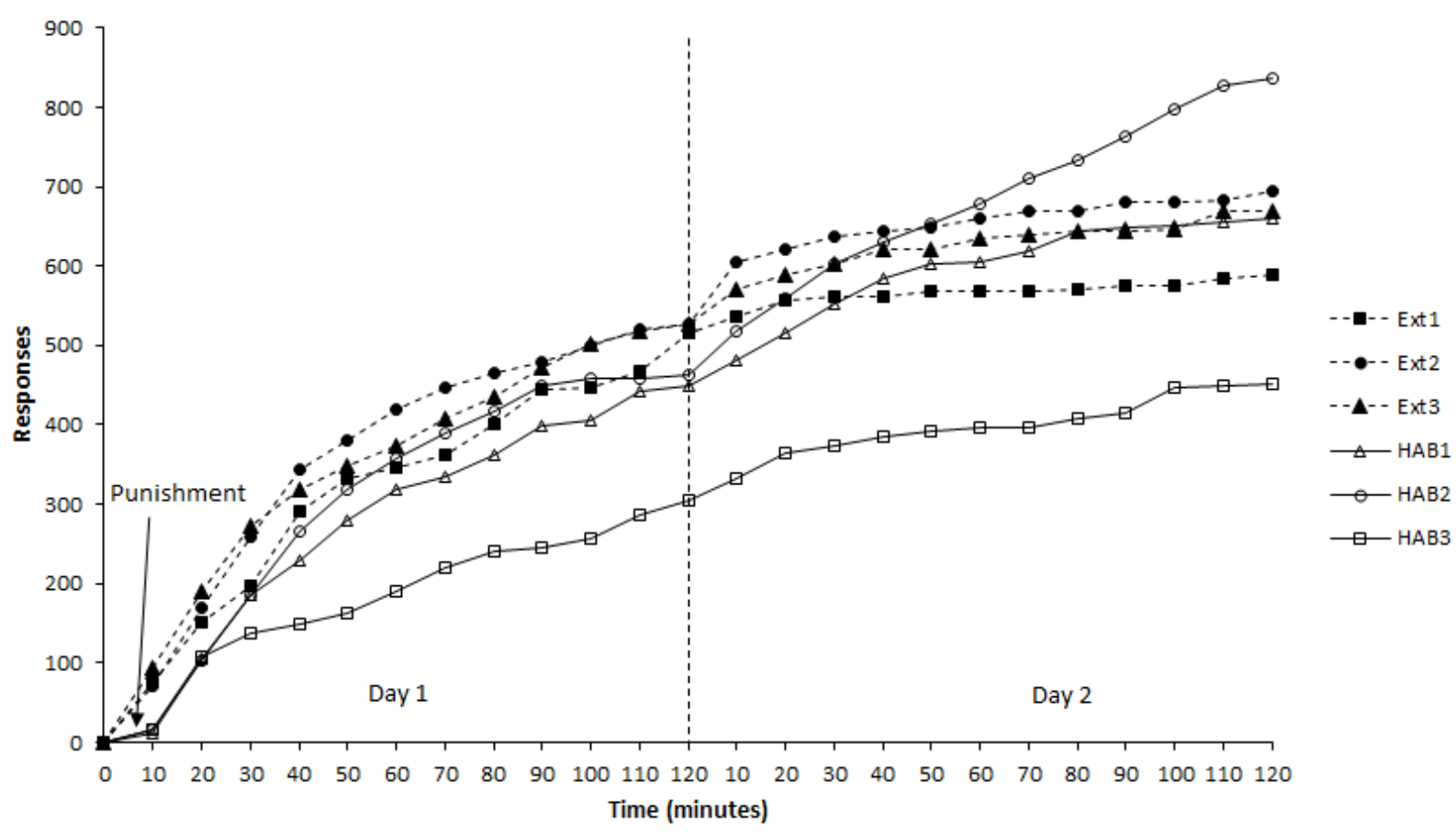

Figure 2. Individual cumulative records of lever presses during Phase 3. Dashed lines and filled shapes correspond to subjects in the Extinction group. Solid lines and open shapes correspond to subjects in the HAB group.

A detailed set of data from Phases 2 and 3 is presented in Table 1 . Subjects in the HAB group made an average of $14 \%$ more lever presses in Phase 2 (training) than subjects in the Ext group. The number of $\mathrm{HAB}$ exposures equated with the number of responses during the initial 10 min of the first extinction session (Ext1[10']) in Phase 3 and varied between 11 for subject HAB1 and 16 for subject HAB2. 
Table 1.

Individual and Mean Lever Press Responses in Each Session in Phases 2 and 3. Ext1(10') Indicates the Number of Lever Presses During the First 10 min of the First Extinction Session.

\begin{tabular}{lllllllll}
\hline & \multicolumn{3}{l}{ Extinction Group (EXT) } & \multicolumn{5}{c}{ Hot Air Blast Group (HAB) } \\
& Ext1 & Ext2 & Ext3 & Mean & HAB1 & HAB2 & HAB3 & Mean \\
\hline FI1 & 884 & 597 & 745 & 742 & 835 & 701 & 1146 & 894 \\
FI2 & 729 & 902 & 921 & 850.7 & 1110 & 658 & 899 & 889 \\
FI3 & 587 & 851 & 755 & 731 & 935 & 726 & 941 & 867.3 \\
FI Mean & 733.3 & 783.3 & 807 & 774.6 & 960 & 695 & 995.3 & 883.4 \\
EXT1(10') & 76 & 70 & 95 & 80.3 & 11 & 16 & 15 & 14 \\
EXT1+EXT2 & 590 & 695 & 670 & 651.7 & 659 & 836 & 451 & 648.7 \\
\hline
\end{tabular}

\section{DISCUSSION}

The present study reproduced the results that were reported by Skinner (1938/1991), in which subjects that were exposed to punishment made fewer responses during punishment and recovered responding after punishment ceased, presenting a similar total number of responses as the unpunished group by the end of the experiment. Table 1 shows no linear relationship between the number of responses during training (Phase 2) and Extinction (Phase 3) in the EXT group. The data from the HAB subjects, however, suggested an inverse relationship between the total number of lever presses in Phase 2 and the number of responses during extinction, which was contrary to expectations. The total number of contacts with the punisher was not a predictor of the maintenance of suppression; the subject that was most exposed to the punisher also made more responses during extinction (subject HAB2).

To account for these similar results, Skinner $(1938 / 1991)$ referred to competitive responses (i.e., conditioned or unconditioned) that were elicited. Although Skinner did not present any description of these alleged competitive responses and they were not recorded in the present study, Silva, Carvalho Neto, and Mayer (2014) both recorded and described such responses that were produced by activation of the HAB. A range of responses that could compete with lever pressing, such as stretching the body on the floor, sniffing the ceiling, and exploring the chamber, were documented and could also have interfered with lever pressing in the present study.

The counterintuitive relationship between the number of responses during training and extinction (after punishment) and the higher range of individual differences in the HAB group appears to be consistent with Skinner $(1938 / 1991,1953)$, in which punishment may have an "emotional" effect. In this case, suppression of the punished response occurs not through legitimate operant learning but rather through a disruption of ongoing behavior (see Church, 1969). Similar effects are produced when an abrupt and sudden environmental change occurs, such as a loud noise. Even if this event is unrelated to any behavior, it may make the subject stop what it is doing, resulting in heart rate acceleration, startle responses, freezing, or changes in attentional states. Because of the short exposure to the HAB (between 11 and 16 contacts) and because it was a stimulus that produced a very drastic environmental change (i.e., noise, heat, and blast), the subjects may have still been adapting to its novelty, and no genuine operant stimulus-response learning occurred. A replication of this study using response-independent presentations of the HAB would be an interesting way to test this hypothesis.

Nonetheless, we do not suggest that competitive responses or emotional states may be the cause of suppression in all punishment scenarios. In Boe and Church (1967), for example, suppression was maintained after $9 \mathrm{~h}$ of extinction. Therefore, it would not be parsimonious to suppose that the alleged competitive responses (i.e., the emotional reaction to punishment) were still in effect to prevent the punished operant from occurring.

Rachlin (1966) observed two effects when a mild shock was used as punishment: (1) strong and immediate suppression of responding that dissipates and is unrelated to the correlation between the consequence and the response and (2) gradual stabilization of the levels of suppression that depend on the correlation between the response and the consequence. This author argued that these two effects overlap when intense electric shocks are applied. The first effect lasts longer, and the second appears sooner, resulting in a direct decrease in the probability of responding.

According to Bolles, Uhl, Wolfe, and Chase (1975), learning a response-consequence relationship may require several occurrences. In their study, rats were exposed to response-independent shocks in the absence of light and to contingent shocks in the presence of light. These rats required more than 30 sessions to exhibit differential response suppression between conditions, and learning occurred gradually. Moreover, the subjects that were initially exposed only to the contingent discriminated punishment increased their responses when the free-shock condition was added. These results indicate that long exposures to punishment 
conditions may be necessary for the contingency to be learned and that the eliciting properties of electric shocks do not always compete with the operant and are not solely responsible for suppression.

When we apply the analyses of Rachlin (1966) and Bolles et al. (1975) to the present experiment, longer exposures to the punishment procedure would be needed for effects on response probability to be observed (i.e., a lower number of responses during extinction as suggested by Skinner, 1938/1991). The present experiment also raises concerns regarding the search for a single explanation for the suppression of responding by punishment. Considering the variety of procedures, arrangements, and stimuli (e.g., electric shock, response cost, noise, light, drugs), a reasonable possibility is that more than a one mechanism of suppression may be in effect in these different conditions. Some combinations may produce suppression through indirect mechanisms, as suggested by Skinner (1938/1991, 1953), and other combinations may reflect a direct learning process as suggested by Azrin and Holz (1966). If so, then such perspectives would help explain the lack of consensus on this subject and orient empirical investigations and theoretical synthesis in a more productive direction (Carvalho Neto, Mayer \& Ferreira, 2017).

The issue of response recovery in punishment experiments is also complex. Response recovery has been described in the literature using different terms, such as habituation (Linscheid, Iwata, Rickets, Williams, \& Griffin, 1990), behavioral contrast (Azrin \& Holz, 1966), resurgence (Okouchi, 2015), behavior release (Rasmussen, 2006), renewal, reinstatement, lapse, and relapse (Bouton, 2014; Bouton \& Schepers, 2015). Each of these constructs is based on different assumptions and independent variables. This results in a large and complex dataset that is difficult to group and compare because of their procedural and theoretical diversity.

With regard to specifically the $\mathrm{HAB}$, despite the response recovery that was observed, it suppressed responding while in effect. The $\mathrm{HAB}$ is a compound stimulus, and its aversiveness appears to be related to a combination of its properties. When only the sound or sound plus air blast without heat were used as a consequence of responding (e.g., lever pressing in rats), little or no suppression was observed, even by the end of the first session (Rodrigues, Nascimento, Cavalcante, \& Carvalho Neto, 2008). In contrast, relatively constant suppression by $\sim 90 \%$ was found during 20 sessions of punishment when all of the properties of the HAB (i.e., sound, blast, heat) were used (Carvalho Neto et al., 2007). Yet another study indicated that the aversiveness of the $\mathrm{HAB}$ is progressive and appears to be effective after at least 3s of exposure (Mayer et al., 2015). Further studies are needed to determine the extent of similarities between the HAB and electric shock.

The present study adds to the behavioral literature by providing another replication of a classic and widely cited study using a novel aversive stimulus. We reproduced the results of Skinner (1938) and raise important questions that will encourage further studies. When Skinner's experiment was previously replicated with an electric shock, the intensity of the stimulus was shown to be a critical variable for the maintenance of suppression (Boe \& Church, 1967). In the present study, although the stimulus produced reliable and stable suppression of behavior (i.e., no recovery while the punishment contingency was in effect), the response recovered after punishment was discontinued, indicating that the initial suppression of responding may not necessarily be indicative of long-term effectiveness of the punishment procedures. It also raises the issue that stimuli that produce drastic environmental changes (e.g., in the present study, noise + heat + air blast) may take longer to produce operant learning (i.e., an association between the response and consequence). This calls attention to variables that may be related to the different processes that are involved in the suppression of responding.

\section{REFERENCES}

Arbuckle, J. L. \& Lattal, K. A. (1987). A role for negative reinforcement of response omission in punishment. Journal of the Experimental Analysis of Behavior, 48(3), 407-416.

Azrin, N. H. \& Holz, W. C. (1966). Punishment. In: W. K. Honig (Ed.), Operant behavior: areas of research and application (pp. 380-447). New York: Appleton-Century-Crofts.

Barker, D. J., Sanabria, F., Lasswell, A., Thraikill, E. A., Pawlak, A. P., \& Kileen, P. R. (2010). Brief light as a practical aversive stimulus for the albino rat. Behavioural Brain Research, 214(2), 402-408.

Boe, E. E., \& Church, R. M. (1967). Permanent effects of punishment during extinction. Journal of Comparative and Physiological Psychology, 63(3), 486-492.

Bolles, R. C., Uhl, C. N., Wolfe, M., \& Chase, P. B. (1975). Stimulus learning versus response learning in a discriminated punishment situation. Learning and Motivation, 6(4), 439-447.

Bouton, M. E., \& Schepers, S. T. (2015). Renewal after the punishment of free operant behavior. Journal of Experimental Psychology: Animal Learning and Cognition, 41(1), 81-90.

Bouton, M. E. (2014). Why behavior change is difficult to sustain. Preventive Medicine, 68, 29-36.

Branch, M. N., Nicholson, G., \& Dworkin, S. I. (1977). Punishment-specific effects of pentobarbital: dependency on the type of punisher. Journal of the Experimental Analysis of Behavior, 28(3), 285-293.

Carvalho Neto, M. B., Costa, J. R., Barros, R. S., Farias, D. C., \& Rico, V. V. (2013). Discriminação com três diferentes contingências em $\mathrm{S} \Delta$ : extinção, reforçamento e punição, extinção e punição. Interação em Psicologia, 17(2), 171-179.

Carvalho Neto, M. B., Maestri, T. C., \& Menezes, E. S. R. (2007). O jato de ar quente como estímulo aversivo: efeitos de sua exposição prolongada em Rattus norvegicus. Acta Comportamentalia, 15(2), 171-190. 
Carvalho Neto, M. B., Maestri, T. C., Tobias, G. K. S., Ribeiro, T. C., Coutinho, E. C. N. N., Miccione, M. M., Oliveira, R. C. V., Ferreira, F. S. S., Farias, D. C., \& Moreira, D. (2005). O jato de ar quente como estímulo punidor em Rattus norvegicus. Psicologia: Teoria e Pesquisa, 21(3), 335-339.

Carvalho Neto, M. B., Mayer, P. C. M., \& Ferreira, P. A. (2017). Simetrias e assimetrias entre reforçamento e punição: Uma proposta taxonômica. Acta Comportamentalia, 25(1), 73-84.

Catania, A. C. (1998). Learning, 4th ed. Upper Saddle River: Prentice Hall.

Church, R. M. (1969). Response suppression. In: B. A. Campbell \& R. M. Church (Eds.), Punishment and aversive behavior (pp. 111-156). New York: Appleton-Century-Crofts.

de Villiers, P. A. (1980). Toward a quantitative theory of punishment. Journal of the Experimental Analysis of Behavior, 33(1), 15-25.

Dinsmoor, J. A. (1998). Punishment. In: W. T. O'Donohue (Ed.), Learning and behavior therapy (pp. 188-204). Boston: Allyn \& Bacon.

Estes, W. K. (1944). An experimental study of punishment. Psychological Monographs, 57(3), 140.

Flaherty, C. F. (1985). Animal learning and cognition. New York: McGraw-Hill.

Kubanek, J., Snyder, L. H., \& Abrams, R. A. (2015). Reward and punishment act as distinct factors in guiding behavior. Cognition, 139, 154-167.

Lerman, D. C., \& Vorndran, C. M. (2002). On the status of knowledge for using punishment: implications for treating behavior disorders. Journal of Applied Behavior Analysis, 35(4), 431-464.

Linscheid, T. R., Iwata, B. A., Rickets, R. W., Williams, D. E., \& Griffin, J. C. (1990). Clinical evaluation of the self-injurious behavior inhibiting system (SIBIS). Journal of Applied Behavior Analysis, 23(1), 53-78.

Maestri, T. C. (2008). O estudo do desamparo aprendido em função de dois estímulos aversivos: jato de ar quente e choque elétrico. Unpublished masters thesis. São Paulo: Instituto de Psicologia, Universidade de São Paulo.

Mayer, P. C. M., Silva, G. F., \& Carvalho Neto, M. B. (2015). Punishment of instrumental and consummatory responses with a hot air blast in rats. Behavior Analysis: Research and Practice, 15(1), 58-64.

Nascimento, G. S., \& Carvalho Neto, M. B. (2011). Supressão condicionada com diferentes estímulos aversivos: choque elétrico e jato de ar quente. Acta Comportamentalia, 19(3), 269-280.

Nascimento, G. S., Monteiro, P. C. M., Gouveia Jr., A.., \& Carvalho Neto, M. B. (2012). Subchronic effects of fluoxetine on conditioned suppression produced by a hot air blast. Psychology and Neuroscience, 5(1), 117-122.

Okouchi, H. (2015). Resurgence of two-response sequences punished by point-loss response cost in humans. Revista Mexicana de Análisis de la Conducta, 41(2), 137-154.

Paton, J. J., \& Louie, K. (2012). Reward and punishment illuminated. Nature Neuroscience, 15(6), 807-809.

Rachlin, H., \& Herrnstein, R. J. (1969). Hedonism revisited: on the negative law of effect. In: B. A. Campbell \& R. M. Church (Eds.), Punishment and aversive behavior (pp. 83-109). New York: Appleton-Century-Crofts.

Rachlin, H. (1966). Recovery of responses during mild punishment. Journal of the Experimental Analysis of Behavior, 9(3), 251-263.

Rasmussen, E. B. (2006). "Behavior-releasing” effects of drugs: anti-punishment and anti-conflict procedures. Revista Mexicana de Análisis de la Conducta, 32(1), 73-91.

Rasmussen, E. R., \& Newland, M. C. (2008). Asymmetry of reinforcement and punishment in human choice. Journal of the Experimental Analysis of Behavior, 89(2), 157-167.

Rodrigues, B. D., Nascimento, G. S., Cavalcante, L. C., \& Carvalho Neto, M. B. (2008). Efeitos da punição de uma classe de respostas usando diferentes dimensões e intensidades do jato de ar quente. Brazilian Journal of Behavior Analysis, 4(2), 231241.

Sidman, M. (1989). Coercion and its fallout. Boston: Authors Cooperative.

Silva, G. F., Carvalho Neto, M. B., \& Mayer, P. C. M. (2014). O jato de ar quente como estímulo aversivo antecedente. Acta Comportamentalia, 22(2), 135151.

Skinner, B. F. (1938/1991). The behavior of organisms: an experimental analysis. Cambridge: B.F. Skinner Foundation.

Skinner, B. F. (1953). Science and human behavior. New York: MacMillan.

Submetido em 27/09/2016 Aceito em 10/05/2017 